УДК 373.3.016.78-053.5

DOI:

Денис Маковський, аспірант кафедри теорії $і$ методики музичної освіти та хореографії Мелітопольського державного педагогічного університету імені Б. Хмельницького

\title{
ОСОБЛИВОСТІ ПРОВЕДЕННЯ ФОРМУВАЛЬНОГО ЕКСПЕРИМЕНТУ З МЕТОДИКИ ФОРМУВАННЯ ЗДАТНОСТІ ДО РОЗУМІННЯ МУЗИКИ УЧНІВ ПОЧАТКОВОЇ ШКОЛИ НА УРОКАХ МИСТЕЦТВА
}

У статті представлено результати формувального експерименту з формування здатності до розуміння музики в учнів початкової иколи на уроках мистецтвва. Автор визначає, шуо для ефективності результатів проведення формувального експерименту з учнями початкової иколи необхідним с створення нових форм, методів та прийомів. Встановлено, щуо успішність впровадження розробленої методики підтверджено в ході формувального експерименту, в результаті якого виявлено позитивну динаміку формування здатності до розуміння музики в учнів початкової иколи на уроках мистецтва.

Ключові слова: формувальний експеримент; розуміння музики; учні початкової иколи; урок мистецтвва. Puc. 1. Лim. 6.

Denys Makovskiy, Postgraduate Student of the Theory and Methods of Music Education and Choreography Department Melitopol Bohdan Khmelnytskiy State Pedagogical University

\section{THE FEATURES OF FORMATIVE EXPERIMENT CONDUCTING ON THE METHODS OF FORMING THE ABILITY FOR UNDERSTANDING OF MUSIC OF PRIMARY SCHOOL STUDENTS IN ART LESSONS}

In the article the results of a formative experiment on the formation of the ability to understand music of primary school students in art lessons are presented. The author determines that for the effectiveness of the results of the formative experiment with primary school students it is necessary to create new forms, methods and techniques.

It is proved that the educational process according to the experimental method in EG in comparison with CG, helped to increase the general results of the formation of the ability to understand music of primary school students in art lessons. An analysis of the results of the initial and final sections in the experimental group of primary school students states that there was an increase in the number of children with a high level of ability to understand music: EG (initial) from $7.5 \%$ to $28.3 \%$ EG (final). In the control groups, a significant increase in high levels was not detected: CG (initial) - from $8.3 \%$ to $13.3 \%, C G$ (final). It was found that due to the increase of high levels in the experimental group decreased their average level of formation of the ability to understand music from $53.3 \% E G$ (initial) to $20.0 \%$ in EG (final).

It is established that the success of the implementation of the developed methodology was confirmed during the formative experiment, as a result of which the positive dynamics of the formation of the ability to understand music of primary school students in art lessons was revealed. It is outlined that the research materials can serve as a theoretical basis for the development of prospective models of forming the ability to understand music of primary school students in art lessons based on the use of the methods, forms and means of different types of musical activities.

Keywords: formative experiment; understanding of music; primary school students; art lesson.

П остановка проблеми. Шлях європейської та світової інтеграції, обраний Україною, зумовлює необхідність реформаційних процесів в освітній галузі, спрямованих на досягнення найкращих освітніх стандартів. Питання, пов'язані з освітою музичного мистецтва у молодших школярів висвітлюються в багатьох сучасних роботах, зокрема у працях та інших дослідників. Проте, зважаючи на значний науковий доробок учених, ми хочемо долучитися до окресленої проблеми і посприяти підвищенню рівня формування здатності до розуміння музики в учнів початкової школи на уроках мистецтва шляхом упровадження у освітній процес авторської моделі.

Аналіз останніх досліджень і публікацій. Цінний досвід досліджень щодо проблеми виховання і навчання музичного мистецтва у молодших школярів зокрема, таких як: розвиток музичних здібностей [2]; формування музичних знань молодших школярів засобами мультимедійних технологій [6]; розвитку образного сприймання музики молодшими школярами [4, 95-100]; формування моральноестетичних почуттів молодших школярів [5, 387391]; формування музичної культури молодших школярів [1]; навчання сольфеджіо молодших школярів у спеціалізованих мистецьких 


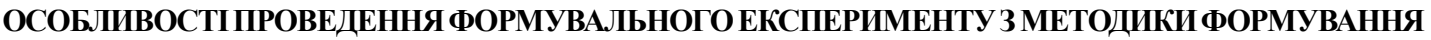 ЗДАТНОСТІ ДО РОЗУМІННЯ МУЗИКИ УЧНІВ ПОЧАТКОВОӤ ШКОЛИ НА УРОКАХ МИСТЕЦТВА}

навчальних закладах [3]. Однак, формування здатності до розуміння музики в учнів початкової школи на уроках мистецтва науковці пропонують різні підходи.

Отже, метою статті $є$ розкриття дієвих форм, методів, аналіз результатів експериментального дослідження щодо формування здатності до розуміння музики в учнів початкової школи на уроках мистецтва.

Виклад основного матеріалу. Загальна мета формувального експерименту полягала в оцінці ефективності впровадження методичної системи формування здатності до розуміння музики в учнях початкової школи на уроках мистецтва.

Ефективність теоретико-методичної системи формування здатності до розуміння музики в учнів початкової школи на уроках мистецтва визначалась у процесі порівняння результатів вихідного та підсумкового діагностувального зрізів. Ми здійснили порівняння результатів формувального експерименту між рівнем сформованості здатності до розуміння музики в учнів початкової школи на уроках мистецтва експериментальних і контрольних груп.

Рівень сформованості здатності до розуміння музичного мистецтва у молодших школярів визначався за результатами інтерв'ювання, анкетування, бесіди, тестових завдань (в ігровій формі), педагогічного спостереження та за допомогою методів статистичної обробки експериментальних даних.

Після завершення експериментальної роботи з учнями експериментальних і контрольних груп було проведено інтерв'ювання у ході якого з'ясовувалося їх інтерес, особистісне ставлення до уроків мистецтва та музичного навчального процесу.

На перше запитання інтерв”ювання: “Чи любиш ти уроки мистецтва?” відповіді дітей експериментальних і контрольних груп істотно різнилися. Практично всі учні, які навчалися в експериментальних групах на це запитання дали позитивну відповідь, супроводжуючи ії появою хорошого настрою - посмішка, прояв радості тощо. На запитання “Чому?” діти експериментальних груп відповідали, що їм дуже подобається гратися у музичні ігри, музикувати на інструментах, співати, танцювати тощо Відповіді ж учнів контрольних груп, тобто тих, які навчалися музиці традиційно, були досить різноманітними. Однім дітям подобалися уроки мистецтва, особливо дівчаткам і хлопчикам, які були досить комунікабельними й активними у процесі інтерв’ювання. Інші діти говорили, що їм не подобається, інші відповідали, що не знають. Друге запитання “Що тобі подобається найбільше на уроках мистецтва - малювати, ліпити, слухати музику, співати, грати на музичних інструментах, танцювати чи в музичні ігри гратися?” більшість учнів експериментальних груп обрали музичноігрову діяльність. I це зрозуміло, адже для учнів початкової школи ігрова діяльність ще є провідним видом діяльності. Другу позицію в уподобаннях дітей посідала гра на музичних інструментах, далі слідували танці і на останньому спів пісень. Школяри ж контрольних груп у своїх відповідях називали співати, танцювати або виступати на святі. Як свідчить аналіз практичної діяльності багатьох викладачів мистецтва, основним видом їх роботи $€$ підготовка дітей до чергового виступу на святі чи концерті. То ж зрозуміло, що на більшості уроків мистецтва з учнями контрольних груп музично-ігрова діяльність булла відсутня взагалі. Діти дуже часто розучували чергову пісню, рухи танцю, проходили сценарій тощо.

У завдання наступного запитання "Чи любиш ти слухати музику?” входило завдання з'ясувати ставлення учнів початківців до музичного мистецтва зокрема. Дітям експериментальних груп це запитання дещо було незрозумілим. Слухання музики практично завжди було активним 3 додаванням рухів, відтворенням сюжету музичного твору, музикування, малювання тощо. Діти ж експериментальних груп відповідали по-різному одним дітям подобається слухати музику, іншим ні, треті не знали.

Запитання “Яку музику любиш слухати: веселу чи сумну, повільну чи швидку?” мало на меті виявити їх уподобання щодо темпових та емоційних характеристик, які, на наше глибоке переконання були свідченням певного рівня їх емоційно-психологічного стану. Річ у тому, що для нормального емоційно-почуттєвого стану учнів початкових класів є перевага прояву такого емоційного стану, як радісне сприйняття життя. Відповідно таким дітям більше до вподоби весела та швидка музика. Більшість дітей експериментальної групи віддали перевагу саме такій музиці, учні ж контрольної групи обирали різні варіанти відповідей - це і сумна, і весела, це і повільна, і швидка музика.

На запитання “Чи подобається тобі співати?” діти давали різні відповіді, серед них: так, ні і не дуже. Істотно відмінним аспектом відповідей було перевага відповіді “так” в експериментальних групах. В контрольних же группах першу сходинку зайняли відповіді “не дуже”, другу сходинку зайняла відповіді “ні”, відповідно “так” зайняли останню позицію. Варто зазначити, що наші 


\section{ОСОБЛИВОСТІПРОВЕДЕННЯ ФОРМУВАЛЬНОГО ЕКСПЕРИМЕНТУ З МЕТОДИКИ ФОРМУВАННЯ}

ЗДАТНОСТІ ДО РОЗУМІННЯ МУЗИКИ УЧНІВ ПОЧАТКОВОӤ ШКОЛИ НА УРОКАХ МИСТЕЦТВА

спостереження за процесом уподобань дітей на уроках мистецтва показали малий відсоток уподобань набрали саме спів пісень.

На прохання заспівати якусь пісеньку учні експериментальної і контрольної груп продемонстрували відмінні показники під час виконання цього завдання. Надзвичайно яскравою відмінністю була сором'язливість школярів контрольної групи, тоді як учні експериментальної були більш безпосередні й творчо розкутіші. Незначна кількість учнів початкових класів контрольної групи - (14,3%) змогли проспівати перший куплет пісні, яку вони готували до випускного школярів старших класів, тоді як інші-(31,7 \%) відмовлялися від виконання цього завдання. молодші школяри, які навчалися в експериментальної групі змогли продемонструвати вищий показник успішного виконання цього завдання - 43,7 \%. Деякі з них навіть намагалися придумати власну пісеньку про зайчика (вовчика, ведмедика тощо).

На запитання “Чи любиш ти грати на музичних інструментах?” практично всі учні, як експериментальної, так і контрольної груп, відповідали - так. Однак відповіді на "На яких музичних інструментах тобі найбільше подобається грати?” констатували істотні відмінності показників. Практично 86,3 \% учнів експериментальної групи успішно справилися 3 поставленим завданням. Їх відповіді були досить змістовними, як у кількісному, так і у якісному показниках - вони називали різноманітні інструменти - свищик, тріскачка, металофон, ксилофон, фортепіано, гітара, ліра й багато іншого. В контрольній групі лише 26,3\% учнів назвали свої улюблені музичні інструменти і серед відповідей найчастішими “фігурантами” були - маракаси, трикутники й ксилофони.

Наступне запитання “Чи любиш ти танцювати?” мало на меті з'ясувати ставлення учнів початкових класів до музично-танцювальної діяльності. Як доводять наші спостереження за практикою здійснення традиційного музичного розвитку, навчання та виховання дітей молодшого шкільного віку віку цей вид діяльності спрямований в основному на показовий виступ на святі для батьків. Безмежні репетиції викликають у молодших школярів негативне ставлення до цього музично-навчальної діяльності. I цим пояснюється великий відсоток - 61,3 \% учнів контрольної групи, які дали негативну відповідь, 27,0 \% дітей відповіли, що не знають, і лише 11,7 \% учнів дали стверджувальну відповідь.

Майже $100 \%$ позитивних відповідей ми отримали на запитання “Чи любиш ти музичні ігри?”. І це досить передбачувана реакція учнів початкової школи, оскільки для цього віку гра залишається головним видом життєдіяльності. Однак запитання “Які саме і чому?” у більшості учнів контрольної групи викликало ніяковість і певний рівень забудькуватості. Вони довго не могли пригадати назву музичної ігри, яка їм подобається найбільше. Знову ж таки, велика кількість часу, яка витрачається на підготовку учнів до свят, позбавляє дітей від використання такого виду музично-навчальної діяльності як музична гра на заняттях. Учні ж експериментальної групи називали велику різноманітність назв музичних ігор, але перше місце в уподобаннях посідали ігри, які викликають у дітей викид адреналіну - “Пірати і русалки”, “Феї та чаклуни”, “Дельфінчики та акули” тощо.

3'ясування динаміки рівнів сформованості здатності до розуміння музики в учнів початкової школи на уроках мистецтва здійснювалося за схемою кожного структурного компоненту окремо. Результати кінцевого діагностувального зрізу порівнювалися і з результатами учнів контрольної групи.

Отже, на першому етапі кінцевого діагностувального зрізу перед намипостало завдання вияснити рівень розвиненості мотиваційного компоненту розуміння музичного мистецтва учнів четвертого класу. Особистіснозначиме ставлення дітей до уроків мистецтва та музичного навчального процесу, наявності прагнення до успішної музично-навчальної діяльності визначали результати бесіди та інтерв'ювання. Молодші школярі були більш змістовними та відкритими у відповідях.

У результаті бесіди нами було з'ясовано, що учні, які навчалися у контрольній групі мали посереднє відношення до розуміння музики на уроках мистецтва. Вони не могли чітко відповісти чи люблять уроки мистецтва чи ні. Сдине, що ці уроки набагато легше, ніж інші предмети початкової школи. Однак особливого розуміння до музичного мистецтва нами виявлено не було. Натомість відповіді учнів експериментальної групи були переважно позитивними, вони проявляли відкрите захоплення уроками мистецтва, із захватом розповідали, як вони їм подобаються і хочуть, щоб кількість цих уроків була збільшена, які мінімум до двох разів на тиждень.

Деякі педагоги початкових класів відмічали, що після проведення уроків мистецтва 3 використанням методики формування здатності до розуміння музичного мистецтва, учні показували значно кращі результати у процесі 


\section{ОСОБЛИВОСТІ ПРОВЕДЕННЯ ФОРМУВАЛЬНОГО ЕКСПЕРИМЕНТУ 3 МЕТОДИКИ ФОРМУВАННЯ ЗДАТНОСТІ ДО РОЗУМІННЯ МУЗИКИ УЧНІВ ПОЧАТКОВОЇ ШКОЛИ НА УРОКАХ МИСТЕЦТВА}

написання контрольних робіт, тестових завдань тощо.

Динаміка отриманих результатів мотиваційного компоненту експериментальної групи, значно виросла у порівнянні із контрольною групою, результати яких показала незначну динаміку. Так у ЕГ групі вже на самому початку розуміння музики у школі був відсутній низький рівень сформованості здатності до розуміння музичного мистецтва, а загалом, переважав середній та високий. Щодо результатів експериментальної групи учнів початкових класів, то значно виросли показники високого рівня за рахунок чого знизився середній рівень 3 56,7 \% до 26,7 \%. Результати кінцевого зрізу мотиваційного компоненту в учнів контрольної групи істотних зрушень не виявили.

3 метою з'ясування рівня емоційноестетичного компоненту сформованості здатності до розуміння музики в учнів початкової школи на уроках мистецтва нами було проведено низку творчих завдань на визначення рівня розвиненості темпо-метро-ритмічного чуття, звуковисотного слуху, емоційного відгуку на музику тощо. Кінцевий діагностувальний зріз показав наскільки результати в експериментальної групи істотно відрізняються від результатів учнів, які були в контрольній групі.

Наступний етап діагностувального зрізу мав на меті з'ясувати рівень когнітивноінформативного компоненту сформованості здатності до розуміння музики в учнів початкової школи на уроках мистецтва (наявність музичних вмінь, навичок, певного рівня музичної компетентності). У процесі дігностувального зрізу застосовувався методи опитування, тестових завдань та бесіди.

Отримані результати дозволили констатувати наявність позитивної динаміки в рівнях творчодіяльнісного компоненту сформованості здатності до розуміння музики в учнів початкової школи на уроках мистецтва музичної експериментальної групи: високий рівень зріс з 6,7 \% до 33,3 \% в ЕГ. За рахунок підвищення високого рівня середній рівень знизився з 50,0 \% до 16,7\% в ЕГ, а низький рівень знизився 3 13,3 \% до 3,3 \% в ЕГ. Молодші школярі контрольної групи показали значно гірші результати: високий рівень піднявся лише з 13,3 \% до $16,7 \%$ в КГ, достатній рівень піднявся 326,7 \% до $36,7 \%$ в КГ, а низький рівень знизився $313,3 \%$ до $10,0 \%$.

Враховуючи результати початкового та кінцевого зрізів в експериментальної групі учнів початкових класів варто констатувати, що відбулося збільшення кількості дітей з високим рівнем сформованості здатності до розуміння музики: ЕГ (поч.) з 7,5 \% до 28,3 \% ЕГ (кін.). У контрольних групах значного збільшення показників високого рівня не виявлено: КГ (поч.) - $38,3 \%$ до $13,3 \%$, КГ (кін.). За рахунок збільшення показників високого рівня в експериментальній групі знизились їх показники середнього рівня сформованості здатності до розуміння музики $353,3 \%$ ЕГ (поч.) до $20,0 \%$ в ЕГ (кін.). Кількість дітей із достатнім рівнем сформованості здатності до розуміння музики в КГ піднялася з 23,3 \% до 26,7\%, а 3 середнім знизились 3 50,0 \% до 46,7 \%.

За час педагогічного експерименту значна кількість учнів експериментальної групи знизила показники низького рівня: ЕГ (поч.) 3,3 \% до відсутності низького рівня. В контрольної групі показники низького рівня знизились наступним чином: з 18,3\% до 13,3\%.

Проведений формувальний експеримент підтвердив ефективність розробленої на основі обгрунтованих педагогічних умов методики формування здатності до розуміння музики в учнів початкової школи на уроках мистецтва (див. рис. 1). В учнів початкової школи, які входили до експериментальної групи, відбулися статистично достовірні кількісні та якісні зміни, що виявилися в позитивній динаміці рівнів формування здатності до розуміння музики на уроках мистецтва. зокрема, зменшилась кількість учнів з низьким рівнем, натомість зросла із середнім. Позитивна динаміка спостерігається також у зміні кількості молодших школярів із достатнім рівнем, певні зрушення були і у показниках, що засвідчили зростання високого рівня здатності до розуміння музики на уроках мистецтва.

Висновки і перспективи подальших наукових розвідок. Отримані результати надають підстави зробити висновок, що реалізація ефективних форм, методів через визначені педагогічні умови і принципи стимулюють формування здатності розуміння музики в учнів початкової школи на уроках мистецтва, сприяють більш глибокому розумінню понять музичного мистецтва, засвоєнню музичних знань, а також формуванню емоційно-ціннісного ставлення до оточення. Перспективою подальшого дослідження є розкриття ефективності процесу музичної освіти іншої дитячої вікової групи.

\section{ЛІТЕРАТУРА}

1. Грисюк О.М. Формування музичної культури молодших школярів в умовах взаємодії загальноосвітньої і дитячої музичної шкіл: дис... канд. пед. наук: Ніжинський держ. педагогічний 


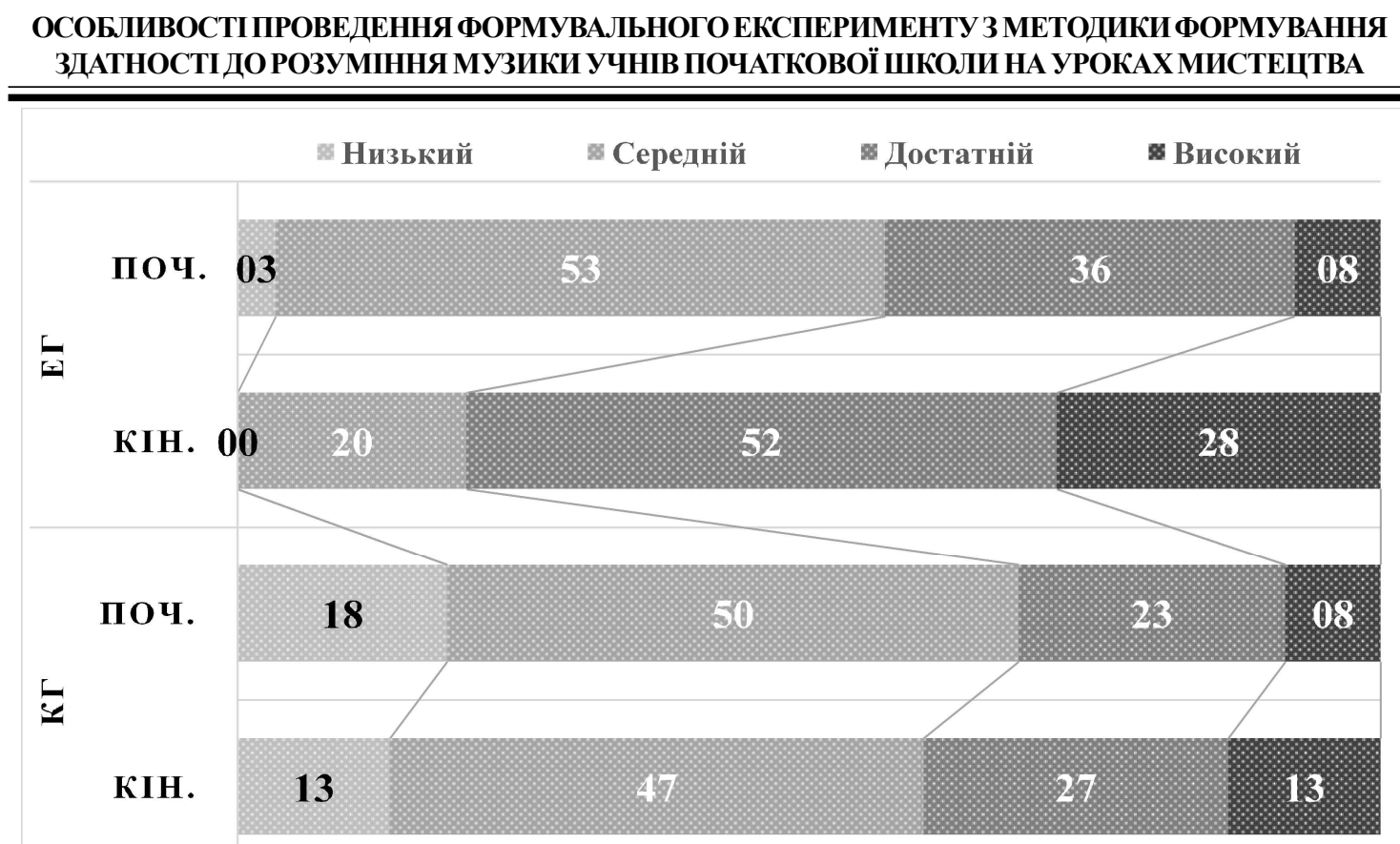

Рис. 1. Динаміка рівнів формування здатності до розуміння музики в учнів початкової школи на уроках мистецтва

ун-т ім. Миколи Гоголя. Ніжин, 1999. С.160 179.

2. Коваль О. В. Формування музичних здібностей молодших школярів на уроках музики : дис. ... канд. пед. наук : (спеціальність 13.00 .02 “Теорія і методика музичного навчання"), Ніжинський держ. педагогічний ун-т ім. Миколи Гоголя. Київ, 2002. $251 \mathrm{c}$.

3. Мудролюбова I. О. Методика навчання сольфеджіо молодших школярів у спеціалізованих мистецьких навчальних закладах автореф. дис. на здобуття канд. пед. наук: (спеціальність 13.00.02. “Теорія і методика музичного навчання"). Київ, 2016. 20 с.

4. Прокофьєва Л.Б. Образне сприймання музики молодшими школярами як педагогічна проблема. Актуальні проблеми теорії музики та музичного виховання: Зб. наук. праць. Київ, 1997. С. 95-100.

5. Процюк В. М. Підготовка майбутніх учителів музики до формування у молодших школярів морально-естетичних почуттів засобами музичного фольклору в процесі педагогічної практики. Сучасні інформаційні технології та інноваційні методики навчання в підготовці фахівців: методологія, теорія, досвід, проблеми. Вінниця, 2007. С. 387-391.

6. Чайковська О.А. Досвід організації музичної підготовки молодших школярів з використанням комп'ютерних програм. Інформатика та комп'ютерно-орієнтовані технології навчання: Зб. наук. праць Всеукраїнської науково-практичної конференції (м.Хмельницький, 16-18 травня 2001 року), Київ, 2001. С.57-59.

\section{REFERENCES}

1. Grisyuk, O.M. (1999). Formuvannya muzychnoyi kultury molodshykh shkolyariv $\mathrm{v}$ umovakh vzayemodiyi zahalnoosvitnoyi i dytyachoyi muzychnoyi shkil [Formation of musical culture of junior schoolchildren in the conditions of interaction of general education and children's music schools]. Candidate's thesis. Nizhyn state. Pedagogical University named after Nikolai Gogol. Nizhyn, pp.160 -179 . [in Ukrainian].

2. Koval, O.V. (2002). Formuvannya muzychnykh zdibnostey molodshykh shkolyariv na urokakh muzyky [Formation of musical abilities of junior schoolchildren at music lessons]. Candidate's thesis. Nizhyn state. Pedagogical University named after Nikolai Gogol. Kyiv, 251 p. [in Ukrainian].

3. Mudrolyubova, I.O. (2016). Metodyka navchannya solfedzhio molodshykh shkolyariv u spetsializovanykh mystetskykh navchalnykh zakladakh [Methods of teaching solfeggio to junior schoolchildren in specialized art schools]. Extended abstract of candidate's thesis. Kyiv, 20 p. [in Ukrainian].

4. Prokofieva, L.B. (1997). Obrazne spryymannya muzyky molodshymy shkolyaramy yak pedahohichna problema [Figurative perception of music by junior schoolchildren as a pedagogical problem]. Actual problems of music theory and music education. Kyiv, pp. 95-100. [in Ukrainian].

5. Protsyuk, V.M. (2007). Pidhotovka maybutnikh uchyteliv muzyky do formuvannya u molodshykh shkolyariv moralno-estetychnykh pochuttiv zasobamy muzychnoho folkloru $\mathrm{v}$ protsesi pedahohichnoyi 
praktyky [Preparation of future music teachers for the formation of moral and aesthetic feelings in junior schoolchildren by means of musical folklore in the process of pedagogical practice]. Modern information technologies and innovative teaching methods in training: methodology, theory, experience, problems. Vinnytsia, pp. 387-391. [in Ukrainian].

6. Tchaikovsky, O.A. (2001). Dosvid orhanizatsiyi muzychnoyi pidhotovky molodshykh shkolyariv z vykorystannyam kompyuternykh prohram [Experience of organizing music training of junior schoolchildren with the use of computer programs]. Informatics and computer-oriented learning technologies: Coll. Science. Proceedings of the AllUkrainian Scientific-Practical Conference (Khmelnytsky, May 16-18, 2001), Kyiv: Pedagogical Thought, pp.57-59. [in Ukrainian].

Стаття надійшла до редакції 20.05.2020

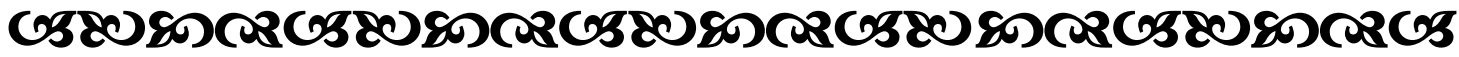

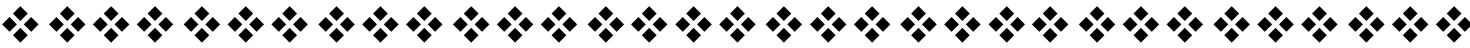

“Успіхи науки - діло часу і сміливості розуму”.

\section{Bольтер \\ франиузький бфілософб}

"Розвинені почуття, висоқа емочійна қультура - ие, образно қажучи, абсолютний музичний слух моральної вихованості".

“... Жбоб відқрити перед учнями іскорку знань, учителю треба ввібрати море світла, ні на хвилю не відходячи від променів вічно сяючого сония знань людсьқої мyдрості".

"Не можна уявити собі місії вихователя без багатого життя в світі книг. Бібліотека вчителя, що поповнюється з тижня на тиждень,- це джерело думки, моральної енергії. Знання, взяті з книг, стають його власним багатством, його сумлінням. Справжній учитель переживає знання якрадість особистого прилучення до духовних багатств, створених людством".

" $C$ дуже чікава зақономірність педагогічної прачі: передача знань не відбувається прямолінійно - ось це учитель сьогодні взнав $і$ ось це він передає свойм вихованиям. Убоге й обмежено життя шқолярів, учитель яқих поқладається лише на те, що напередодні уроку ніде і візьме те, що необхідно віддати, передати".

Василь Сухомлинський украӥнський педагог

\section{G5808}

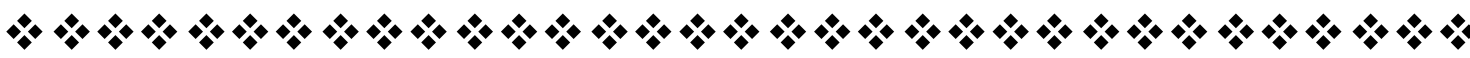

